\title{
Research on Ecological Ethics Thoughts Reflected from the Faulkner's Novels
}

\author{
Wenna Cui ${ }^{1,}$, Xiaojuan $\mathrm{Wu}^{1, \mathrm{~b}}$ \\ ${ }^{1}$ Nanchang Institute of Science \& Technology, Nanchang, 330108, China

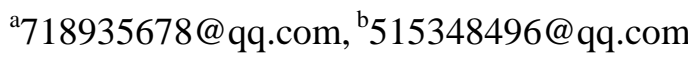

Keywords: ecological ethics; Faulkner's novels; William Faulkner

\begin{abstract}
Faulkner's novels not only reveal the ethical relationship between man and nature, but also reveal Faulkner's complex passion for nature and his concern for human alienation. Faulkner's portrayals of reckless invasion of human, weak resistance of nature and inevitable recession of ecology under the background of human civilization warn people to be in awe of nature. Faulkner's novel points out that it is necessary to reconstruct a good ecological relationship between man and nature, which reflects the author's ecological ethics beyond the times.
\end{abstract}

\section{Introduction}

William Faulkner is one of the most important figures in the American literary world and is regarded by international critics as one of the most outstanding novelists in the United States in the twentieth century [1]. Faulkner won the Nobel prize for literature for his unique contribution to the power and artistry of modern American novels. In the novel, Faulkner depicts the true contradiction between man and nature, showing his deepest love and bitter hatred of the land of this misery. Go Down, Moses is one of the recognized masterpieces of Faulkner, composed of seven short stories that are relatively independent and intertwined. Modern critics think it is a unified novel that contains two themes: race and nature. This novel is based on McCaslin family of several generations of experience, depicts many unique characters, they are connected through a complex family across generations of kinship. In his works, the description of social changes in the South runs through all kinds of spatial narrative techniques. With his unique style, Faulkner created a virtual and complete society based on the various experiences of his life. The emotional expression is extremely delicate, the position of the interlaced time and space is just right, and it also makes the thoughts of the Oriental researchers deep in it and set off a wave of research. By examining novel McCaslin family spanning more than a century of daily life, reflecting the old south between the United States and the New South conflict and conflict between man and nature. The field of vision is very deep. Its handling of slavery, race, class and gender problems is greatly enlarged by joining the relationship between human dilemmas and other basic problems, including land ownership and the connection between human and natural environment. Faulkner's novels reflect natural destruction, alienation of human nature, the relationship between man and nature and human beings, slavery, race and land ownership [2].

\section{Wilderness Characteristic in Faulkner's Novels}

\subsection{Ancient Wilderness}

For some American writers at the end of nineteenth Century, they linger in the wilderness is full of original pure and mysterious place in the imagination, it represents freedom, goodness and non-human beauty, is contrary to constraints, greed, profit and the so-called industrial civilization, is a rebirth. Holmes Rolston expressed a similar view: wasteland provides the most profound historical museum for everything, as a tangible heritage wilderness in which we live, to make us understand to immortality, and the end of the long stretches, significance. At the beginning of the fifth novel Go Down, Moses, Faulkner showed that the wilderness was his clear position in the relationship between 
man and nature. The bear is a development clue to the growth of a white young began to follow the Indian Hunter Sam Fazes into the forest hunting. During hunting, he accepted the spiritual baptism of the laws of nature from the wilderness and Sam, and deep in his soul the awe of the wilderness. In the "old people", Ike in the first stag hunt in life, perceived wilderness is a huge "omniscient and omnipotent God, careful, impartial and omniscient". After 6 years of becoming a formal hunter, Ike is very conscious of the wilderness, the size of the forest, and the old, without any document contract. The hunters who live with humility and skill, with hope and perseverance, take the wilderness as a community. Compared to the vast and old of the wilderness, human beings are too small. In Faulkner's view, man and nature should be equal, and should follow the morality of nature, not the control and destruction of all things. In the wild, people get the inexhaustible wealth of survival in nature, find shelter and food to survive in the primeval forest [3].

\subsection{Omniscient Wilderness}

Faulkner is influenced by the spirit of all things in the world view of Indian, and thinks that the soul or spirit exists in any living or inanimate entity. In the Go Down, Moses, the omniscience is the characteristic of the wilderness. He feels that the wilderness is "deep, perceptive, huge and pondering, where he can travel freely". On the other hand, the wilderness also uses their versatile knowledge to observe them. In the old class, the bear's perception is earlier than Ike's perception of it. When Ike learned the old class the breakout around him, he said to Sam: "you mean he's know me, know that I have never been to dawn." When the knocking of the woodpecker stopped suddenly, he "knew that the bear was looking at him," but he never saw it. When he told Sam about all this, Sam said, "I know," "he's here to watch." He thinks the wilderness, the big forest "is big, the old, is not see any document contract," he said, "it is never mine, I have no right to give up it." It never belongs to the father and uncle Buti, it never belongs to my grandfather, it never belongs to ancestors, bought the land is equal to what people did not buy." In a private society, the possession of land means possessions, rights and social status. Because of the desire for control and possession of human beings, it is inevitable that it is opposed to nature. He thinks that land does not belong to people, and human beings want to work together in society like brothers and sisters, using land instead of private possession. He gave up material, life, family, and returned to the forest and turned to nature. The wilderness is the habitat of a lifetime. The words and behavior showed his attitude towards the land. At the same time, it was Faulkner's attitude towards the land, and he longed for harmony with the land and nature [4].

\subsection{Impartial Wilderness}

Justice is another feature of the wilderness. Bucks are as vigilant as hunters, but never afraid or fearful, because they may also be aware of the eyes of the ancient and immortal arbiters. The repeated wall maps of the old and the bears emphasize the divinity of the wilderness. The omniscient God image on the garden wall shows that nothing in the wilderness can escape from the last just trial, so the wilderness no longer pays attention to hunters. It even ignores human's insignificant damage to primitive forests. Another important value of the wilderness is the superpower that makes life a death, a death to a living, and an endless cycle of life. Humans, like other animals living in the wilderness, are part of the natural network. There is no death in the concept of Ike, and death is another form of rebirth. Sam and the old class has not been firmly landing we live, but free to stay in the land, not to live in the land, but the land itself belongs to life, but there are thousands on thousands of each one, are closely related, cannot be separated. Although there are thousands of forms, there is only one law. Provides a broad background and ancient wilderness and forests for animal and human life, and encourage and dominate their activities. The wilderness and the forest, for Ike, are his university, the place of his enlightenment. Pity, humility, bravery, pride and endurance all come from the wilderness and the forest. The feelings of the great forest are unforgettable, not dangerous or particularly harmful, but deep, perceptive, huge and contemplative. Faulkner, as a metaphor of human being belongs to the land, tells us that man is a natural form of life and a part of nature. To maintain their own right of existence, a biological individual must have specific living conditions, such as sunshine air, water, 
region and so on. All creatures in nature are connected to each other, and all have their own right to live. Survival is the instinct of all creatures, such as human, other animals, and even plants. All things are life. They put all things in the same important position of human beings, giving the same rights to nature and human beings.

\section{Wilderness Destruction in Faulkner's Novels}

\subsection{Reckless Invasion of Human}

The relationship between the human and the wilderness has been established very early. However, the harmony between humanity and nature has been destroyed by the harmony of humanitarianism and the rise of the European Renaissance. The development of technology has improved the living conditions and quality of human beings, met the demand for more development of natural resources, made human beings have greater ability and confidence and become the master of nature, and made human beings lack awe when facing and exploring the wilderness. In the early twentieth Century it seemed hard to imagine that one day human beings would have a great influence on the natural environment we depend on for survival. However, Faulkner foresaw the change. In the Go Down, Moses, he depicts the degradation of the natural and cultural systems of interdependent human beings leading to the natural environment. Environmental history founder Donald Vorster has pointed out that the human face of global ecological crisis is not the root of the ecosystem itself, and in our culture system, we only through a clear understanding of our cultural effect on nature, to solve this crisis. The temptation of economic interest inundated the poetic ecological balance between man and nature. When the old grandson of Cas McCaslin Lucas Beauchamp, in hiding the kettle, stumbled upon a gold coin, is obsessed with finding rumors buried in McCaslin manor treasures. He used all kinds of tools to excavate the land to find gold coins. He even cheated salesmen. He used the detector to cheat it into the place where gold coins were hidden ahead of time, and then sold gold coins to salesmen. The impact of the gold - Lucas Beauchamp filled with buried gold idea. It even nearly destroyed his marriage. This is a warning from the spirit of darkness and loneliness, the ancient land, and even the ancient ancestors of their own. The description of Faulkner's sharpness and humor shows that human beings have become increasingly greedy in modern civilization. With the emergence of humanistic consciousness and the development of science and technology, human beings no longer attach importance to the harmonious relationship between human and wilderness.

\subsection{Weak Resistance of Nature}

Nature has also carried out some resistance in such destruction and plundering. The indomitable old class is still fighting for himself and other life in the wilderness. Though he has lost three toes in the trap, he has been filled with old bullets under his fur. The old class represents the vanishing wilderness, the old class has experienced and struggle is now experiencing the wilderness. This wilderness is doomed, the edge being human plow and axe away. In the eyes of Faulkner, is hunting and gallop in the wilderness the old class is not even a dead animal, but a product of a residue down from the ancient past the unyielding and unconquerable anachronism, the old wild life of a phantom, an epitome and apotheosizing typical. Though in the eyes of him, the wilderness cannot be conquered, destroyed or subsided, but in the face of human invasion, the wilderness is just like the old class, and is already walking ahead and struggling. In his view, human beings can truly return to the harmony with nature in the process of population growth, urbanization, industrialization, commodity economy and self-evaluation, so that we can truly return to the harmony with nature, so that we can have real civilization. This behavior leads to the result, some important ones wantonly break, serious environmental pollution, land desertification and other phenomena, which seriously affect the survival of mankind. The great writers often have sensitive insight and profound creative ideas, and pay attention to human existence in the form of literary perspective. Faulkner explained the human existence by paying attention to the right to existence of nature. The right to existence, also known as "natural rights", refers to all creatures in nature, including animals, plants and microbes. Once they 
are in existence, they have the right to continue to exist according to their own laws. American writers have a tradition of integrating nature and describing nature, forming simple natural consciousness and ecological ethics thought. Severely punish human beings and suppress human nature superior God is not the God of the Puritan tradition, but with mercy and tolerance to appear in front of human beings. The author deeply criticized the persecution of slavery and racism against blacks, and traced a study of this system from the perspective of private ownership. It can be said that Faulkner is the ultimate source of God through human moral consciousness, moral judgment of the supreme authority to express their moral ideal. By nature, without love blindly explore nature, which is always to be a natural retaliation.

\subsection{Inevitable Recession of Ecology}

The mysteries of the wilderness disappear in the interpretation of science. Human beings no longer use the wilderness with fear and awe, which leads to its inevitable death. He saw the mongrel "Lion" and Boone and the old class of fierce fighting, finally, the old class and the "Lion" die, but not tired of the old class "soft down, but like a tree like straight down". Even in the tragic moment of death, the old class in the "flat" image symbolizes noble nature and unyielding, however, the old class and death is inevitable, brought by industrial civilization and determines its resistance is futile. After the news of the old class's death, Sam last saw the old class, and then fell to the ground and died. The inevitable and tragic death of the old class and the death of Sam underline the grief of Faulkner in the face of the death of the wilderness. The old class represents the God of the forest. Sam represents the guardians of the wilderness, and the lion represents a bridge to the new civilization. They all represent the traditional way of hunting. The death of the old class, Sam and the lion symbolizes that the wilderness is approaching death step by step, and the death of a hunting way full of ecological ethics. "The fall of the delta" describes the nearly eighty and the rear students returning to the wilderness for the last hunting. Under the aggression of human civilization, the wasteland retreats. He doesn't sigh, the time has gone. They used cars instead of carriages, driving faster and faster each year, and invaded the natural civilization. But with the invasion of the capitalist industrial and commercial civilization and the expansion of human material desires, the wilderness is doomed to disappear. The disappearance of many civilizations and the various crises that are now being faced are the resistance and retaliatory response of nature to human beings. The attitude of people to nature has been mistaken for many years, that man is the center of the universe and dominates all things in nature. For the sake of its own development, human beings can plunder nature arbitrarily.

\section{Conclusion}

What Faulkner pays most attention to is the human ecology, that is, the interaction between human and its living environment. Faulkner's expression of awe and nostalgia of the wilderness, to worry about the degradation and human spiritual crisis caused by invasion of industrial civilization and human nature. Returning to nature, reconstructing the ecological relationship between people and nature is the deep point of Faulkner's ecological ethics.

\section{References}

[1] Zhu Zhenwu. On the Composition of The Bear and Faulkner S Ecological Ethics [J]. Journal of Shanghai University (Social Sciences), 2014, 31(2): 30-43.

[2] Fang Yanhong. A Comparative Study of Humanism Based on Faulkner s and Wang Zengqi's Literary Works [J]. Shandong Foreign Language Teaching, 2017, 38(4): 64-70.

[3] Zong Rui. On Postcolonial Ecologism in Faulkner's Forest Trilogy [J]. Journal of Nantong Vocational Technical Shipping College, 2017, 16(3): 10-12.

[4] Min Xinzhou. Introduction to American Southern Literature's Influence on the Works of William Faulkner [J]. Education Teaching Forum, 2017(43): 239-240. 